\section{A MCC}

Enrichment plot: ANGIOGENESIS

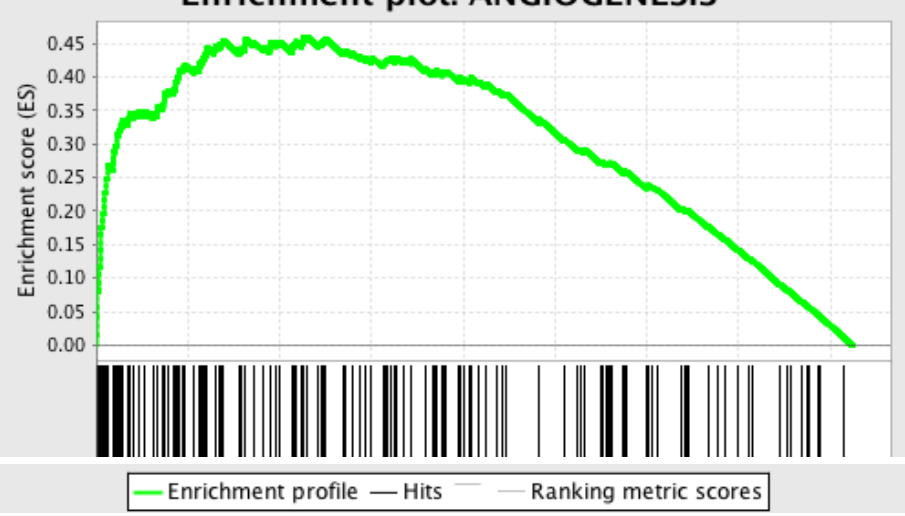

B VUMC

Enrichment plot: ANGIOGENESIS

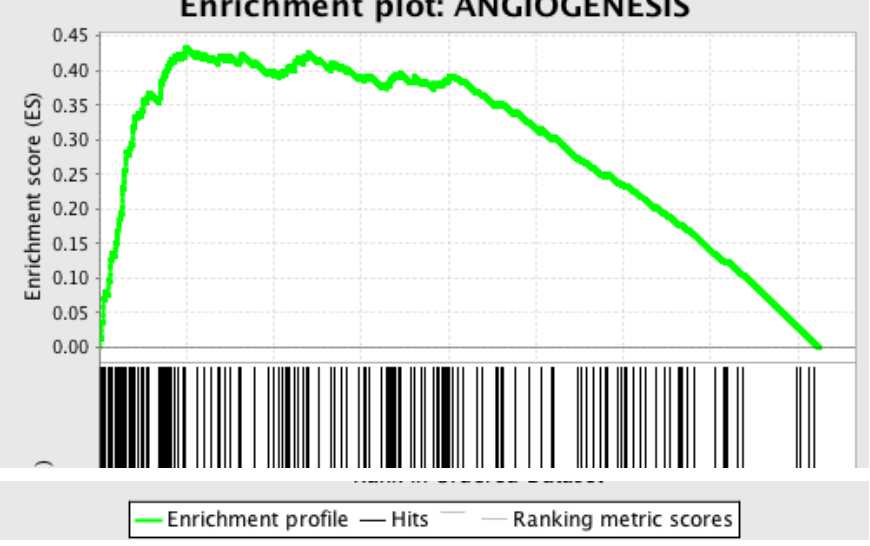

